\title{
Assessment of selected nutrient intake by Polish preschool children compared to dietary recommendations: a meta-analysis
}

\author{
Jana Krzysztoszek ${ }^{1}$, Paweł Kleka², Ida Laudańska-Krzemińska ${ }^{3}$
}

${ }^{1}$ Department of Didactics of Physical Activity, Poznan University of Physical Education, Poznan, Poland

2Institute of Psychology, Adam Mickiewicz University, Poznan, Poland

${ }^{3}$ Department of Physical Activity Study and Health Promotion, Poznan University of Physical Education, Poznan, Poland

Submitted: 18 October 2017

Accepted: 23 January 2018

Arch Med Sci 2020; 16 (3): 635-647

DOI: https://doi.org/10.5114/aoms.2020.93046

Copyright $\odot 2020$ Termedia \& Banach

\section{Abstract}

Introduction: In recent years a steady increase in the number of obese people has been observed worldwide. This problem is also increasingly applicable to children and adolescents. In this study, we conducted a meta-analysis of studies carried out in Poland over ten years (2005-2015) which analysed the diet of preschool children and assessed how significantly it affects the prevention of diet-dependent disease.

Material and methods: Two of the researchers independently performed a systematic search of Medline, Embase, Google Scholar, and the Polish Medical Bibliography to find studies published between 2005 and 2015. The variance of the means of differences between selected factors in relation to dietary guidelines and standards for preschool children was estimated by summing the individual variances of means. The means of differences between selected factors across the studies were pooled using randomeffects model meta-analysis.

Results: The analysis included a total of 2095 children. Mean protein content in the diet of children studied is $111 \%$ higher than indicated in dietary recommendations for this age group; mean consumption of carbohydrates in the study group is $24 \%$ higher than recommended. In moderately high calorie diets, analysis showed that the recommended norm is exceeded by $47 \%$, CE 0.77, $p<0.001$.

Conclusions: Nutrient intake is not compliant with recommendations for this age group and could not only inhibit physical development, but also increase the risk of diet-dependent diseases.

Key words: nutrients intake, preschool children, meta-analysis, dietary recommendations.

\section{Introduction}

Nutritional intake should be appropriate for a person's physiological developmental stage. It should also improve health and help prevent the development of modern civilisation diseases. Abnormalities caused by an excessive or insufficient supply of energy or particular nutrients can lead to health and development disorders. Deficiencies of energy,

\author{
Corresponding author: \\ Jana Krzysztoszek PhD \\ Department of Didactics \\ of Physical Activity \\ Poznan University of Physical \\ Education \\ 27/38 Krolowej Jadwigi St \\ 61-871 Poznan, Poland \\ E-mail: krzysztoszek@awf. \\ poznan.pl
}


proteins, vitamins, or minerals are all serious threats to the developing body of a child. For example, without a sufficient supply of calcium and vitamin $D$ in childhood, optimum bone density cannot be reached in adulthood [1], while iron deficiency negatively affects motor development and increases the risk of infection [2]. On the other hand, excessive consumption of food causes excessive supply of energy and nutrients, which may further cause increased body weight and, later, also the development of civilisation diseases.

Obesity is the result of many factors, of which environmental factors have been receiving the greatest attention for many years. In the last ten years however, increasing significance has also been given to the role of vitamin $D_{3}$ in the organism's metabolism, as well as the effect of vitamin $D_{3}$ deficiency on the development of overweight and obesity in populations of children and adolescents, and adults [3-10]. It has been demonstrated that the active form of vitamin $D$ can affect the expression of over 200 genes [3]. When this vitamin is deficient, glucose metabolism and other metabolic processes in adipose tissue and other tissues can be adversely affected and insulin activity can be impeded [8]. Rodríguez-Rodríguez et al. [7] demonstrated that vitamin D deficiency occurred with visceral obesity and with higher body mass index (BMI) values. Gilbert-Diamond et al. [6] found an inverse relationship between vitamin $\mathrm{D}$ concentration in blood and the development of obesity in school-aged children. Foss [9], on the other hand, suggests that simple obesity and metabolic syndrome can result from disturbances in the winter adaptation of the organism's metabolism, which is mediated by the decrease of blood calcidiol. When metabolism switches physiologically to the winter form, energy reserves are accumulated in the form of adipose tissue and thermogenesis increases. Foss also suggests that the prevalence of obesity is higher in persons in whom the winter form of metabolism appears at higher vitamin $D_{3}$ levels, which leads to excessive accumulation of adipose tissue. In the population of developing children and adolescents, it is also significant in the development of obesity that the number and size of fat cells increases when the energy balance is positive. The final number of adipocytes stabilises with the completion of adolescence. Excessive increase of the number of these cells in childhood can lead to the development of obesity in adolescence and adulthood, as the process is irreversible [11-14]. Data from recent years [15-18] indicate that the prevalence of overweight and obesity in this social group is becoming a global epidemic. According to the International Obesity Task Force [19], each year around 400,000 children in Europe are overweight and approximately 85,000 suffer from obesity; one in five children has trouble maintaining normal body weight, and of the 74 million young Europeans aged 4-18 who are overweight (16-22\%), 4-6\% of them are obese. At a national level, the latest data [20] regarding the subject in Poland indicate that overweight is diagnosed in $9.1 \%$ of preschool girls and $9.9 \%$ of preschool boys, while obesity is diagnosed in $7.2 \%$ of girls and $8.4 \%$ of boys.

To ensure the basic metabolism, postprandial thermogenesis, meeting physical activity needs, and the maintenance of a normal course of growth processes related to synthesis of new cells and tissues, human nutrition norms were developed in Poland in 2008 and also apply to preschool children [21]. These recommendations were updated in 2012 [22], and in 2017 [23] recommendations on the use nutraceuticals and functional foods were published. Uniform international normal levels were introduced (EAR, RDA, Al, UL) to help not only evaluate intake or plan individual and group levels, but also facilitate the exchange of information about epidemiological phenomena such as overweight and obesity with other European countries. If these recommendations are followed, both overfeeding - leading to overweight and obesity - and malnutrition - leading to worse development - can be avoided, especially since there is an increasing amount of proof that the effects of inadequate nutrition are not only observable in childhood, but also are the cause of potential health deterioration in adulthood. Taking the above into consideration, we decided to determine the dietary intake (energy, macronutrient, vitamin and mineral intakes) in the diet of Polish children. In this study, we conducted a meta-analysis of studies carried out in Poland in the past ten years that analysed the intake of the critical nutrients important for the normal development of preschool children, in order to evaluate them against dietary recommendations and in terms of their significance in prevention of civilisation diseases.

\section{Material and methods}

\section{Literature search}

We sought studies analysing the dietary and eating habits of preschool children (3-6 years) conducted in Poland over a ten-year period. Two of the researchers independently performed a systematic search of Medline, Embase, Google Scholar, and the Polish Medical Bibliography to find studies published between 2005 and 2015. The search for studies was performed in January 2016. The following search strategy terms were used: 'nourishment', 'diet', 'nutrition', 'children', 'kindergarten', 'preschool', '3-6 years', 'Poland', 


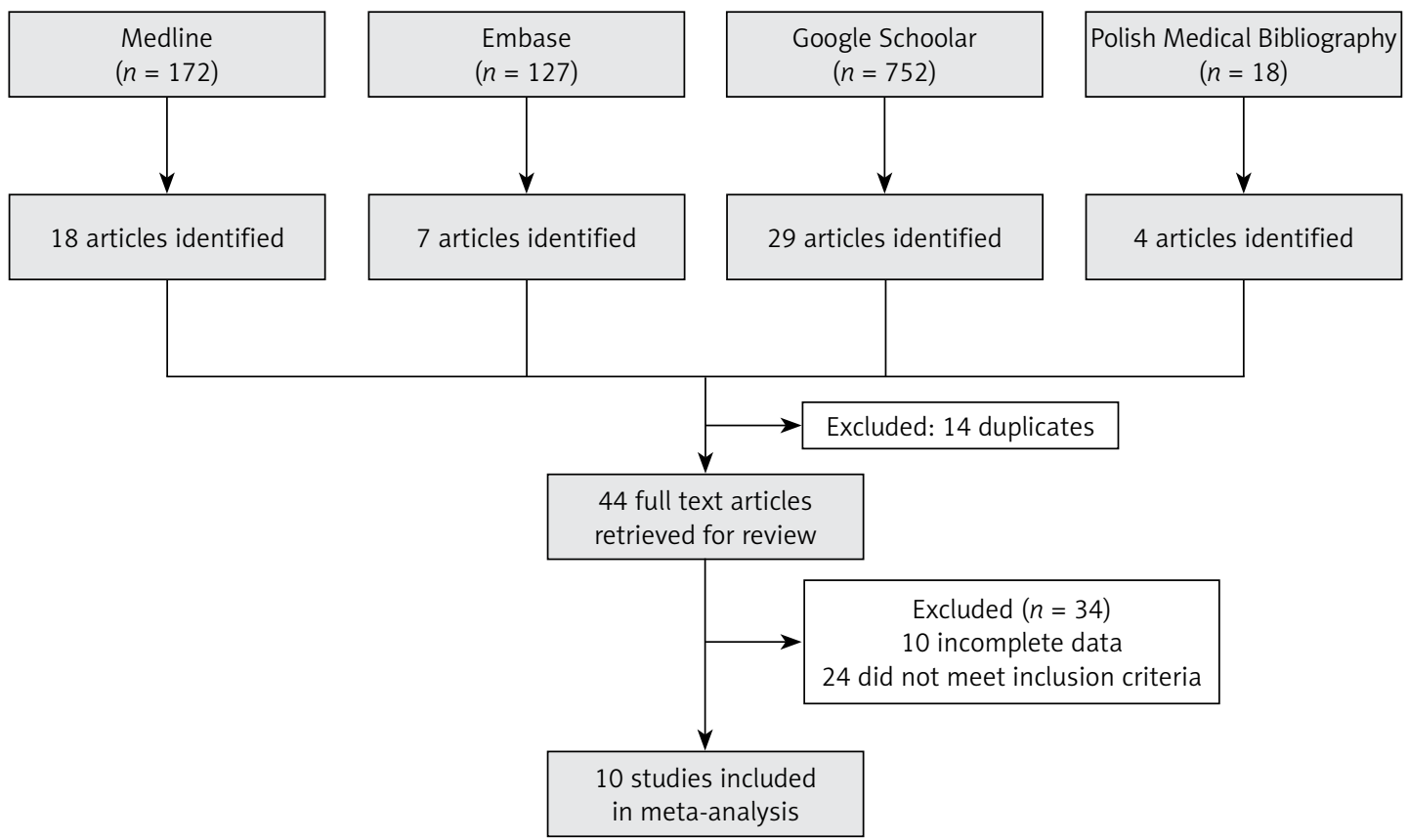

Figure 1. Study flow diagram

'Polish', 'eating habits'. The search included combinations of the terms and the literature search included the reference lists of articles.

\section{Study selection}

We identified citations in Medline (172), Embase (127), Google Scholar (752), and the Polish Medical Bibliography (18). Potentially relevant studies were selected by two authors; the selection was based on pre-defined inclusion criteria and analysis of titles, abstracts, and/or full texts. The inclusion criteria were: (i) subjects: healthy children (without overweight and obesity) of preschool age; (ii) type of study: original study; (iii) time range of publication: 2005-2015. The exclusion criteria were: (i) subjects: children with overweight or obesity and children aged over 6 years; (ii) type of study: analysis of children's eating preferences and/or analysis of menus offered to children in kindergartens. The final report (Figure 1) included ten publications [24-33] that met the inclusion criteria.

\section{Data extraction}

To obtain information from publications, the authors used standardized forms. The following data were extracted: (i) characteristics of children (number, age, gender); (ii) characteristics of research tools; (iii) the average energy value of the analysed diets, (iv) the average daily intake of selected nutrients in the analysed diets (protein, carbohydrates, total fat, fibre, vitamins: $A, E$, $C, D, B_{1}, B_{2}, B_{3}, B_{6}, B_{9}$ and mineral substances: cal- cium, magnesium, phosphorus, iron, sodium, potassium). Data were also sought on differences in regularity of meals, number of meals per day, and snacking between meals, but the data were too limited for analyses.

\section{Comparison with nutritional guidelines}

The energy, macronutrient intakes, vitamin, and mineral intakes of the studied population were compared to dietary reference intakes for the Polish population, including reference intakes for preschool children [34, 35]. The intakes of macronutrients, as well as intakes of vitamins $A, B_{1}$, $\mathrm{B}_{2}, \mathrm{~B}_{3}, \mathrm{~B}_{6}, \mathrm{~B}_{9}, \mathrm{C}$, calcium, phosphorus, magnesium, and iron, were compared to Recommended Dietary Allowances (RDA) [35]. Intakes of vitamin E, sodium, potassium and fibre were compared to Adequate Intake (AI) [35]. Dietary reference intakes for the Polish population do not include EAR/RDA for vitamin D; thus the intake of this vitamin was compared to EAR set by the Food and Nutrition Board of the Institute of Medicine [36]. The assumed recommended daily energy demand (for person/day) in preschool children was $1400 \mathrm{kcal}[34]$.

\section{Data analysis}

As the ten research papers included in the present analysis (Table I) were parts of a single study, we analysed them together, giving a total of 10 data points in the meta-analysis. We estimated the variance of the means of differences between selected factors in relation to dietary guidelines 
Table I. Characteristics of studies included in the present analysis

\begin{tabular}{|c|c|c|c|c|c|}
\hline Study & $N$ & Research tool & $\begin{array}{l}\text { Age of study } \\
\text { population } \\
\text { [years] }\end{array}$ & Survey region & $\begin{array}{l}\text { Study } \\
\text { days }\end{array}$ \\
\hline $\begin{array}{l}\text { Rogalska- } \\
\text { Niedźwiedź } \\
\text { et al. [24] }\end{array}$ & 394 & $\begin{array}{l}\text { Estimated food record for intake, made by } \\
\text { parents. Analyzed using Dieta } 2.0 \text { software }\end{array}$ & 4 & $\begin{array}{l}\text { The whole } \\
\text { country }\end{array}$ & 7 \\
\hline $\begin{array}{l}\text { Gawęcki } \\
\text { et al. [25] }\end{array}$ & 180 & $\begin{array}{l}\text { Food frequency questionnaire. Results } \\
\text { estimated using FOOD software }\end{array}$ & $5-6$ & $\begin{array}{l}\text { Bydgoszcz, } \\
\text { Dąbrowa } \\
\text { Górnicza, Gębice }\end{array}$ & 10 \\
\hline $\begin{array}{l}\text { Sadowska } \\
\text { and } \\
\text { Krzymuska } \\
{[26]}\end{array}$ & 78 & $\begin{array}{l}\text { Estimated food record for intake, made } \\
\text { by parents and another one filled in by } \\
\text { kindergarten staff. Total daily food portions per } \\
\text { child were compared. Analysis performed using } \\
\text { Dietetyk } 2006 \text { software }\end{array}$ & $4-6$ & Szczecin & 3 \\
\hline $\begin{array}{l}\text { Sochacka- } \\
\text { Tatara } \\
\text { et al. [27] }\end{array}$ & 313 & $\begin{array}{l}\text { Estimated food record for intake, made by } \\
\text { parents, analyzed using Nutri-Day software }\end{array}$ & 3 & Kraków & 3 \\
\hline $\begin{array}{l}\text { Sadowska } \\
\text { et al. [28] }\end{array}$ & 105 & $\begin{array}{c}\text { Food frequency questionnaire filled in } \\
\text { by parents and another one filled in by } \\
\text { kindergarten staff. Total daily food portions per } \\
\text { child were compared. Analysis performed using } \\
\text { Dietetyk } 2006 \text { software }\end{array}$ & $4-6$ & Szczecin & 3 \\
\hline $\begin{array}{l}\text { Starbała } \\
\text { et al. [29] }\end{array}$ & 31 & $\begin{array}{c}\text { Estimated food records for menus ( } 2 \text { weekdays } \\
\text { (70\% preschool diet }+30 \% \text { home diet) and } \\
1 \text { day of the weekend). Diets analysed using } \\
\text { Dietetyk software }\end{array}$ & $4-6$ & Warsaw & 3 \\
\hline $\begin{array}{l}\text { Kolarzyk } \\
\text { et al. [30] }\end{array}$ & 324 & $\begin{array}{l}\text { Food frequency questionnaire filled in by } \\
\text { parents }\end{array}$ & $3.5-7.5$ & Kraków & NR \\
\hline Kostecka [31] & 200 & $\begin{array}{l}\text { Food frequency questionnaire a,b filled in by } \\
\text { parents, assessed in Dieta } 5.0 \text { software }\end{array}$ & $3-5$ & Lublin & 3 \\
\hline Merkiel [32] & 120 & $\begin{array}{l}\text { Food frequency questionnaire }{ }^{a, b} \text { filled in by } \\
\text { parents, assessed in Dieta } 4.0 \text { software }\end{array}$ & 6 & Nowy Sącz & 3 \\
\hline Kostecka [33] & 350 & $\begin{array}{l}\text { Food frequency questionnaire }{ }^{\mathrm{a}, \mathrm{b}} \text { (including } 1 \text { day } \\
\text { of the weekend) filled in by parents, assessed } \\
\text { in Dieta } 5.0 \text { application }\end{array}$ & $4-6$ & $\begin{array}{l}\text { South-eastern } \\
\quad \text { Poland }\end{array}$ & 3 \\
\hline
\end{tabular}

aProprietary questionnaire. ${ }^{b}$ Three-day timetable recording the type and quantity of products eaten by the child; filled in by parents and/or kindergarten staff; $N R$ - not reported.

and standards for children aged 3-6 years, by summing the individual variances of means. In order to prevent overestimation of the analysed parameter due to the small number of tests, we multiplied Cohen's $d$ by an additional corrective factor $J$ to obtain the unloaded Hedges' $g$. The variance of the mean of a selected factor was estimated by dividing the difference of the selected factor by the number of participants in the group; when the $S$, standard deviation was unavailable, the square root of the variance gave the standard error (SE) of the mean of this factor. Hedges' categories were used to evaluate the magnitude of the effect size: (i) small if $0 \leq|\mathrm{g}| \leq 0.2$; (ii) medium if $0.2<|\mathrm{g}| \leq 0.5$; (iii) large if $0.5<|\mathrm{g}| \leq 0.8$; and (iv) extra-large if $|\mathrm{g}|>0.8$ [37]. We provided pooled estimates along with their $95 \% \mathrm{Cls}$. We pooled the means of differences between selected factors across the studies using random-effects model meta-analysis, which makes allowance for inter-study heterogeneity. The heterogeneity of the studies was assessed using $Q$ and $l^{2}$ statistics applied to the ES means. The $Q$ statistic is the $\chi^{2}$ test for heterogeneity with a degree of freedom equal to one minus the number of studies included in the meta-analysis; this assesses whether the observed differences of results between studies are due to chance alone [38]. The $I^{2}$ statistic estimates the percentage of total variation across studies due to a true difference rather than chance [39]. In general, $I^{2}$ values greater than $60-70 \%$ indicate substantial heterogeneity. We assessed the influence of the year of studies and differences between regions with ANOVA. The impact of both examined variables was not statistically significant. Statistical tests were two-sided and used a significance level of $p<0.05$. All calculations were performed using $R$ [40] with the Meta for package [41]. 


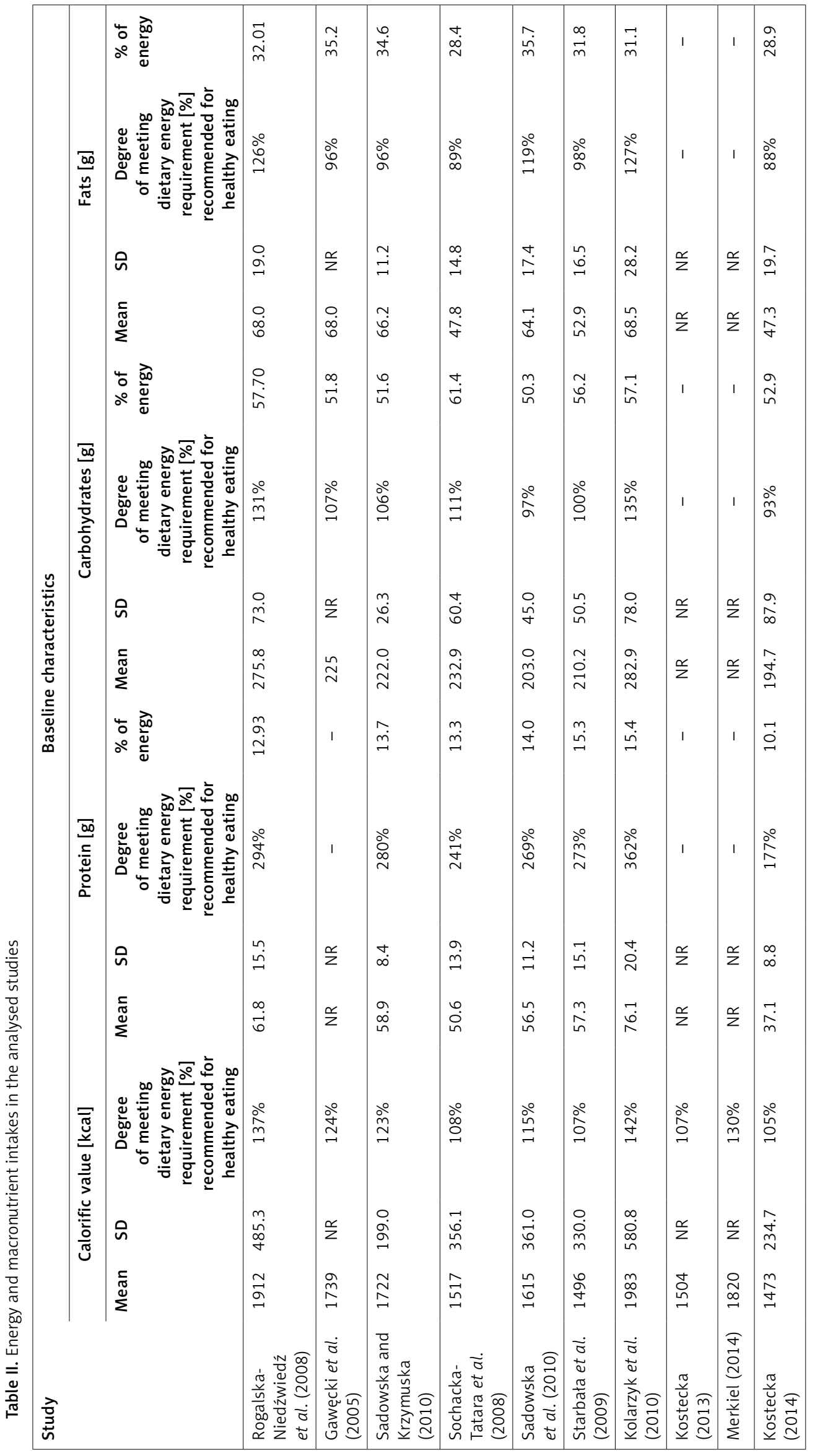




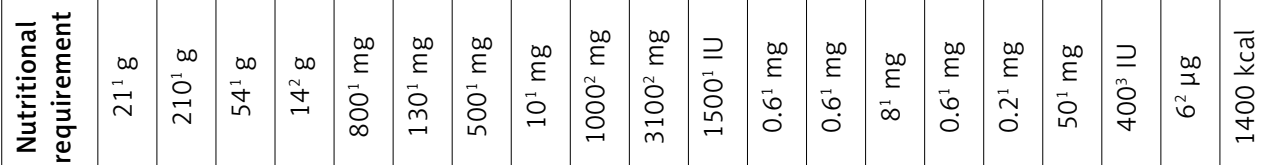

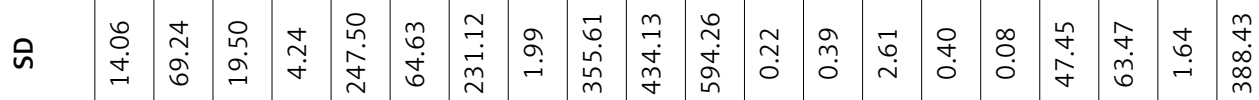

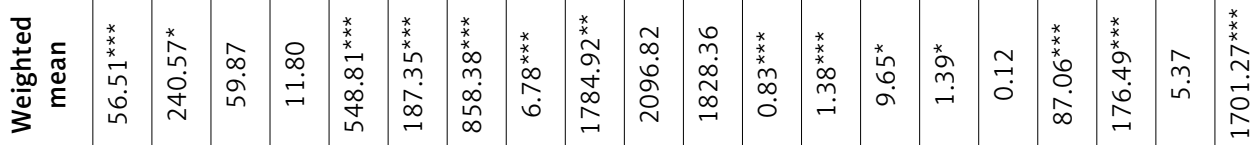

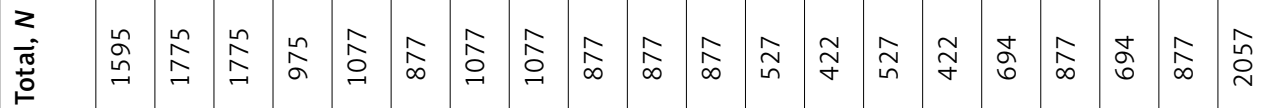

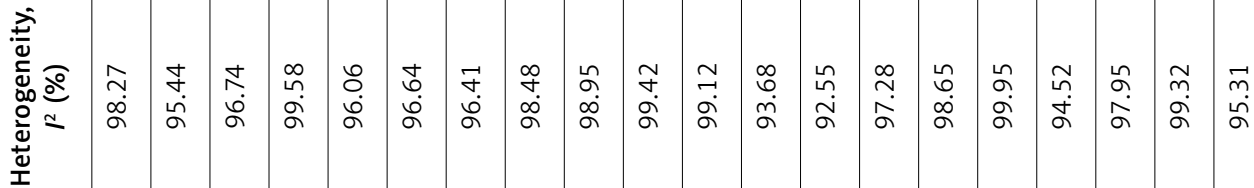

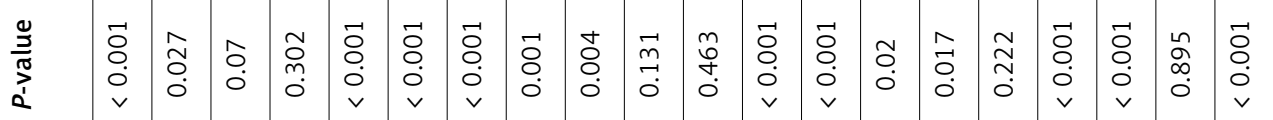

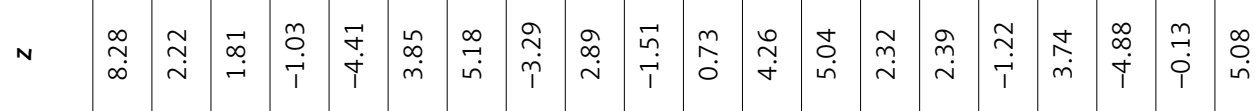

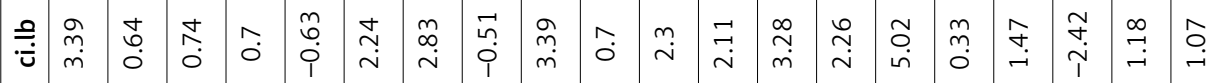

ㅇํํ

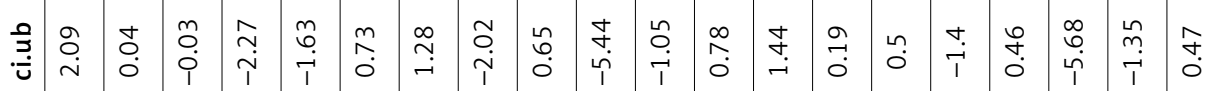

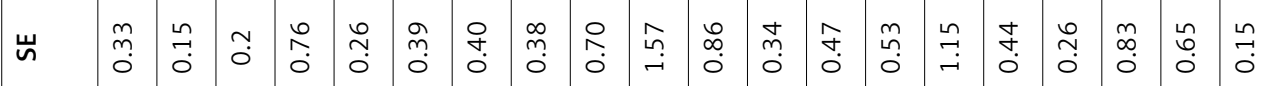

苗

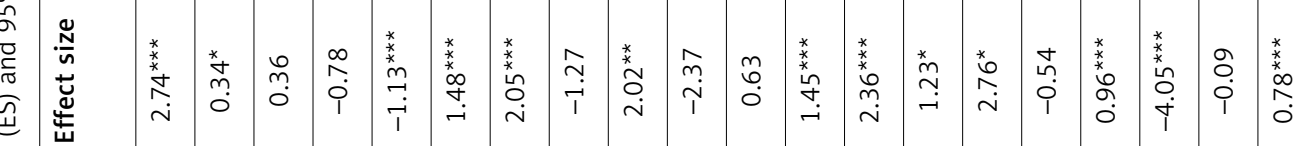




\section{Results}

\section{Participants}

The analysis included a total of 2,095 children. Only one study had a slight predominance of girls (11-58\%), three studies [27, 28, 30] reported no gender distribution, and the in other studies the two genders were roughly equally distributed. Tables I and II present details of the analysed studies. In one of the studies [28], the results were reported in two subsets (obese children and normosthenic children); in accordance with the assumptions and inclusion criteria, only results for normosthenic children were included in the analyses. In the study of Kolarzyk et al. [30], the age range of children included was larger than initially assumed (3.5-7.5), but the study was still includ- ed in the analysis, as the mean age was 5.65. As individual primary studies used different tools to evaluate the effect (various questionnaires), we used the standardized mean difference (SMD). We analysed selected factors separately, which gave a total of 20 comparisons (Table III). Subsets were combined for subsidiary analyses using random-effects model meta-analysis.

\section{Outcomes}

Meta-analysis of combined results from all studies provided a statistically significant cumulative effect (Figure 2). It also improved the reliability of effect assessment. In random-effects model analysis, the obtained cumulative effect (CE) for proteins was statistically significant $(p<0.001)$ at $2.74(95 \% \mathrm{Cl}: 2.09-3.39)$, which

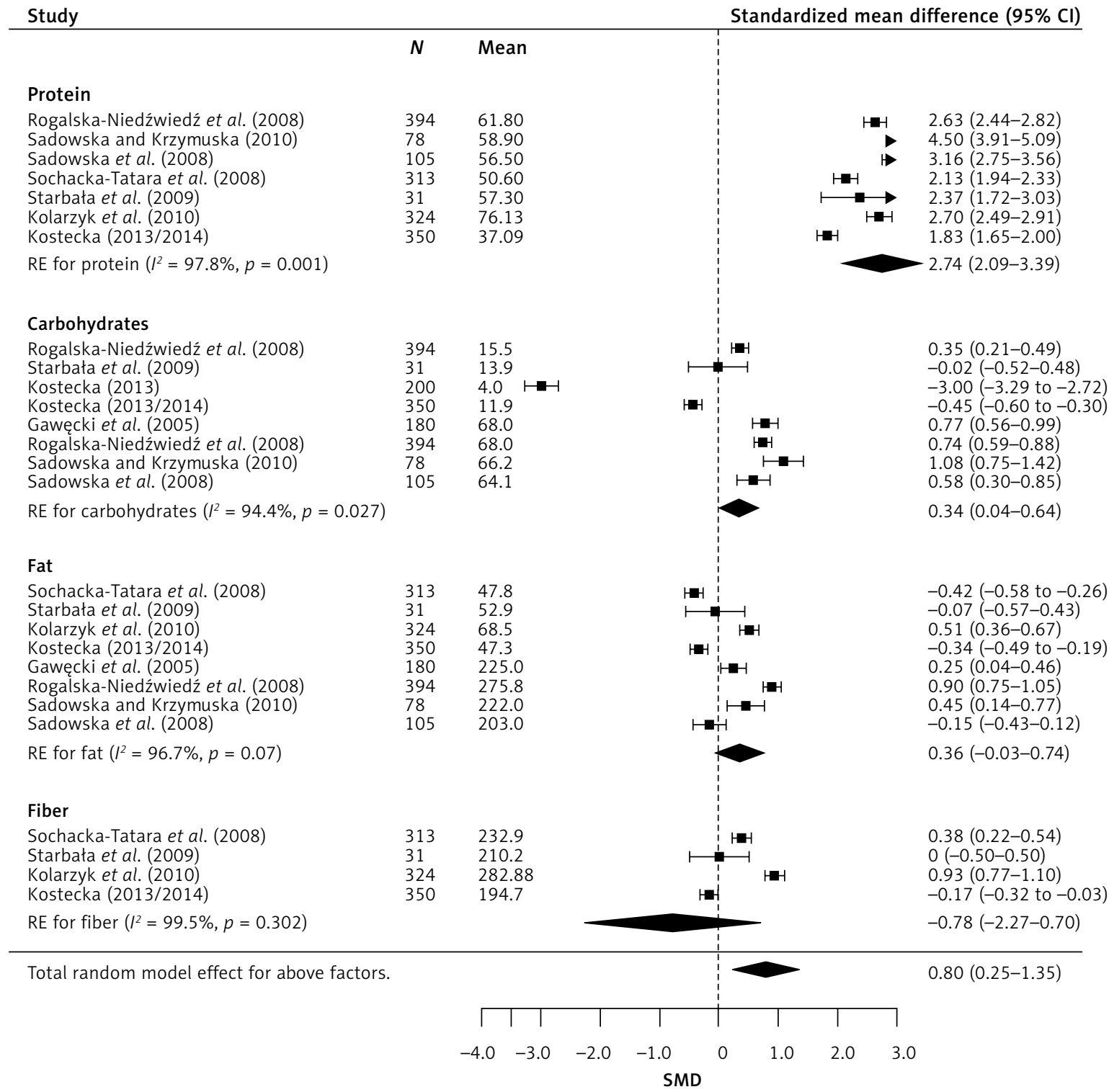

Figure 2. Effect size for standardised mean difference of selected meal parameters 


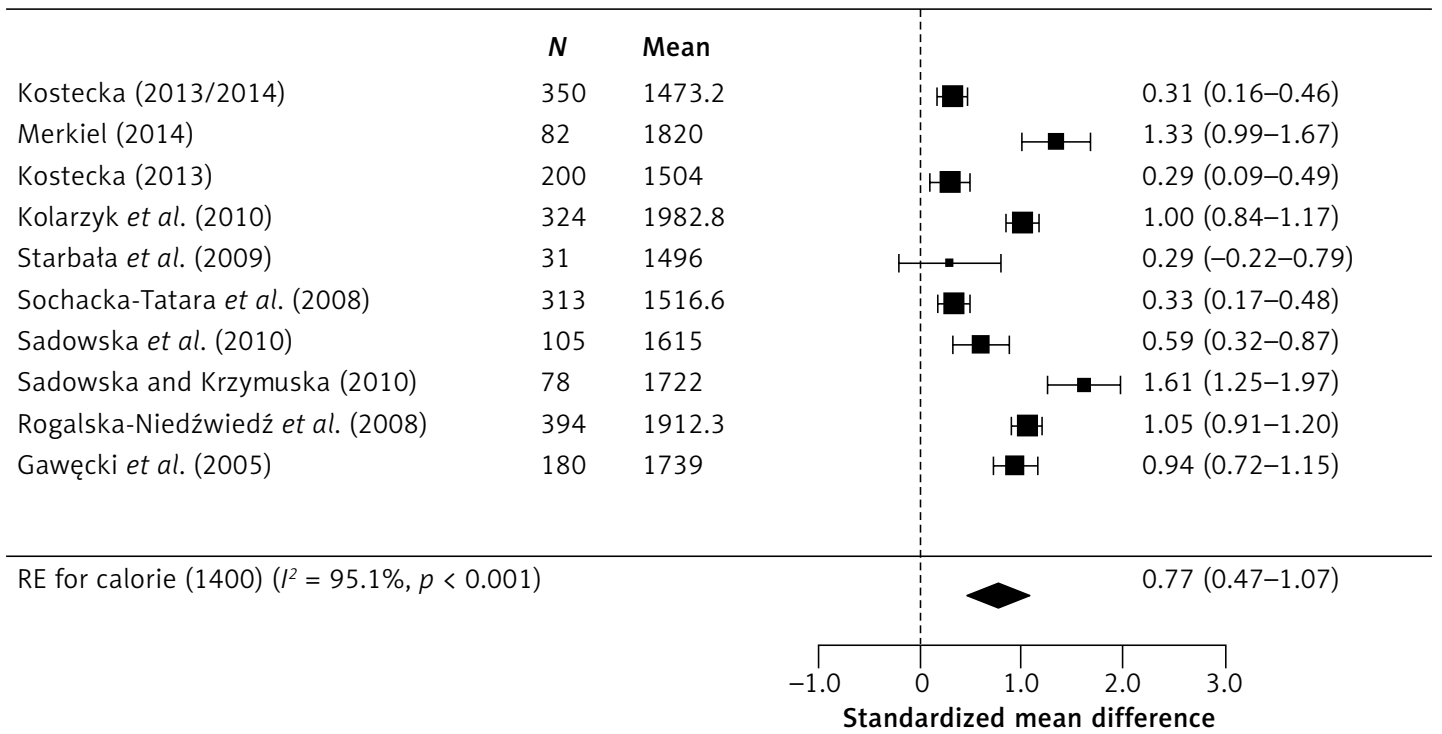

Figure 3. Effect size for standardised mean difference of calorie content $1400 \mathrm{kcal}$

means that the mean protein content in the diet of children studied was $111 \%$ higher [42] than indicated in dietary recommendations for this age group. Similarly, the results for carbohydrates deviate from dietary recommendations, as the CE ( $p=0.027)$ was 0.34 (95\% Cl: 0.04-0.64), which means that the mean consumption of carbohydrates in the study group was $24 \%$ higher than recommended. In moderately high calorie diets, the analysis showed that the recommended norm is exceeded by $47 \%$, CE $0.77, p<0.001(95 \% \mathrm{Cl}$ : 0.47-1.07) (Figure 3).

In the case of micronutrients (Figure 4), statistically significant results were obtained for magnesium CE 1.48 (95\% Cl: 0.73-2.24), phosphorus CE 2.05 (95\% Cl: 1.28-2.83), calcium CE -1.13 (95\% Cl: -1.63 to -0.63 ), and sodium CE 2.02 (95\% Cl: 0.65-3.39). The obtained results indicate significant exceedance of the recommended consumption norms for magnesium (by $72 \%$ ), phosphorus (by $83 \%$ ), and sodium (by $82 \%$ ), while about $63 \%$ insufficiency was observed for calcium. Regarding vitamins (Figure 5), the findings were as follows: severe (about 164\%) vitamin D insufficiency CE -4.05 ( $95 \% \mathrm{Cl}:-5.68$ to -2.42$)$, severe exceedance of the recommended norm for $\mathrm{B}$ vitamins: $\mathrm{B}_{1}-71 \%$, CE 1.45 (95\% Cl: 0.78-2.11), $\mathrm{B}_{2}-$ 96\%, CE 2.36 (95\% Cl: 1.44-3.28), B $-64 \%$, CE 1.23 (95\% Cl: 0.19-2.26), B $-112 \%$, CE 2.76 (95\% Cl: 0.50-5.02), and exceedance of the recommended daily dose of vitamin C by 55\%, CE 0.96 (95\% Cl: 0.46-1.47).

The calculated $Q$ and $I^{2}$ values indicate that the studies were highly heterogeneous, which may be due to inter-study variability caused by the use of different measurement tools and differ- ent methods to calculate the analysed parameters in individual studies.

\section{Discussion}

A properly formulated children's diet, understood primarily as nutrient intake adequate to the demand and meeting energy needs [43], contributes to normal physical development, ensuring optimum weight and height gain, mental capacity, and general health condition. Moreover, low physical activity is not a significant obesity risk factor in children aged 7 to 9 years [44]. In early childhood, somatic development is especially sensitive even to the slightest nutrition inadequacies; moreover, this is the age at which Polish children receive double nutrition (at the kindergarten and at home). Double nutrition means eating meals twice. Most parents and grandparents in Poland collect their children from preschool facilities in the early afternoon hours, immediately or shortly after lunch. Once at home, the child may often eat a second lunch with their parents or grandparents, and are encouraged and praised for eating the whole two-course meal. Carers collecting their children later give them a large warm supper, with the presumption that the child has not eaten enough at preschool. While they provide the correct number (5-6) of meals, carers give children significantly larger amounts of high-calorie foods, rich in carbohydrates and animal protein, which can promote the development of overweight and obesity. This has been confirmed by the above results. The results revealed a series of irregularities in the eating habits of small children. The notably very high intake of protein with vitamins $B_{2}$ and $B_{6}$ 


\section{Phosphorus}

Sadowska and Krzymuska (2010)

Sadowska et al. (2010)

Sochacka-Tatara et al. (2008)

Starbała et al. (2009)

Kostecka (2013/2014)

RE for phosphorus $\left(I^{2}=96.6 \%, p=0.001\right)$

Magnesium

Sadowska and Krzymuska (2010)

Sadowska and Krzymuska

Sochacka-Tatara et al. (2008)

Starbała et al. (2009)
Kostecka (2013/2014)

RE for magnesium $\left(I^{2}=96.4 \%, p=0.001\right)$

\section{Potassium}

Sadowska et al. (2010)

Starbała et al. (2009)
Kostecka (2013/2014)

RE for potassium $\left(l^{2}=98.5 \%, p=0.131\right)$

Sodium

Sadowska and Krzymuska (2010)

Sadowska et al. (2010)

Sochacka-Tatara et al. (2008)

Starbała et al. (2009)

RE for sodium $\left(I^{2}=98.9 \%, p=0.004\right)$

Calcium

Sadowska and Krzymuska (2010)

Sadowska et al. (2010)

Sochacka-Tatara et al. (2008)

Starbata et al. (2009)

Kostecka (2013)
Kostecka $(2013 / 2014)$

$\mathrm{RE}$ for calcium $\left(/^{2}=99.4 \%, p=0.001\right)$

Iron

Sadowska and Krzymuska (2010)

Sadowska et al. (2010)

Sochacka-Tatara et al. (2008)

Starbała et al. (2009)

Kostecka (2013)

Kostecka $(2013 / 2014)$

RE for iron $\left(1^{2}=99.9 \%, p=0.002\right)$
Sadowska and Krzymuska (2010)

$\begin{array}{ll}\boldsymbol{N} & \text { Mean } \\ & \\ 78 & 992.0 \\ 105 & 968.0 \\ 313 & 868.1 \\ 31 & 1079.5 \\ 200 & 1078.6 \\ 350 & 641.6\end{array}$

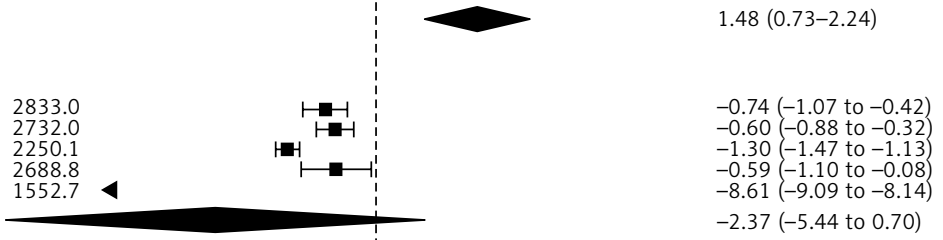

Total random model effect for above factors $\begin{array}{ll}78 & 221.0 \\ 105 & 215.0 \\ 313 & 188.2 \\ 31 & 235.8 \\ 350 & 166.5\end{array}$

641.6

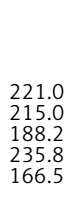

\begin{tabular}{ll}
78 & 283 \\
105 & 273 \\
313 & 225 \\
31 & 268 \\
350 & 155 \\
\hline
\end{tabular}

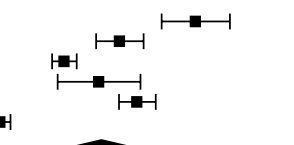

$3.42(2.93-3.92)$
$2.32(1.97-2.67)$
$1.51(1.33-1.69)$
$2.01(1.40-2.63)$
$2.58(2.31-2.84)$
$0.57(0.42-0.72)$

$2.05(1.28-2.83)$

$2.77(2.33-3.20)$
$1.49(1.18-1.79)$

$1.08(0.92-1.25)$

$0.43(0.28-0.58)$

$1.48(0.73-2.24)$

1.07 to -0.42$)$ $-1.30(-1.47$ to -1.13

-8.61 (-9.09 to -8.14$)$

$-2.37(-5.44$ to 0.70$)$

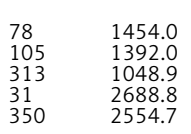

$1.99(1.61-2.37)$

$1.19(0.90-1.48)$

$0.13(-0.02-0.29)$

$2.48(1.82-3.15)$
$4.33(4.06-4.60)$

$2.02(0.65-3.39)$

$-1.64(-2.00$ to -1.28 $-1.49(-1.80$ to -1.19 -0.84 (-1.00 to -0.67$)$ $-0.79(-.62$ to -1.56$)$ $-0.76(-0.91$ to -0.61$)$

$-1.13(-1.63$ to -0.63$)$

$-0.43(-0.75$ to -0.12$)$ $-0.83(-1.11$ to -0.55$)$ $-0.30(-0.81-0.20)$ $-2.82(-3.10$ to -2.55$)$

$-1.47(-1.64$ to -1.31$)$

$-1.27(-2.02$ to -0.51$)$

$0.12(-0.68-0.92)$

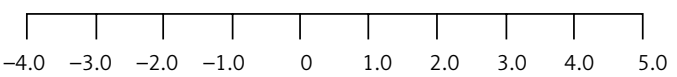

Standardized mean difference

Figure 4. Effect size for standardised mean difference of selected factors

can be due to the consumption of large amounts of meat. In preschool years, physical growth is extremely intensive and the consumption of protein is important during that period. However, protein should not be eaten in large amounts as it places a strain on the liver and kidneys due to the fact that nitric compounds are then excreted [45]. Authors from other countries who analyse preschool children's diet have also noted excessive consumption of protein in their countries. Values for protein slightly lower than in Poland, but exceeding recommendations, were found in 2.5-6.5-year-old [46] and 4-6.5-year-old [47] children in Belgium, in 7-year-old children in the south-west of England [48], and 3-5-year-old children in Greece [49], while values even higher than those found in our meta-analysis were found in 4-5-year-old children in Vietnam [50] and 6-7-year-old children in Spain [51]. A reduction in animal protein intake is recommended as longterm excessive intake of protein entails an increased risk of diabetes [52], as well as premature pubertal onset, which may contribute to a higher risk of breast cancer in women [53].

Positive energy balance is another factor promoting formation of adipose tissue, which was found in the meta-analysis. Considering the fact that the number of overweight children is constantly on the increase [15-19], the results obtained by our meta-analysis and reports from authors in other countries (similarly high exceedance of recommendations was reported in 5-11-yearold children in France [54], in 6-7-year-old children in Spain [41], in 5.7-7.6-year-old children 
Vit. A

Sadowska and Krzymuska (2010)

Sadowska et al. (2010)
Sochacka-Tatara et al. (2008)

Starbała et al. (2009)
Kostecka (2013/2014)

RE for vit. A $\left(I^{2}=99.5 \%, p=0.464\right)$

Vit. $B_{1}$

Sadowska and Krzymuska (2010)

Sadowska et al. (2010)

Sochacka-Tatara et al.
Starbała et al. (2009)

RE for vit. $B_{1}\left(l^{2}=99.1 \%, p=0.001\right)$

Vit. $B_{2}$

Sadowska and Krzymuska (2010)

Sochacka-Tatara et al. (2008)

Starbała et al. (2009)

RE for vit. $B_{2}\left(I^{2}=93.7 \%, p=0.001\right)$

Vit. $B_{3}$

Sadowska and Krzymuska (2010)

Sadowska et al. (2010)

Sochacka-Tatara et al. (2008)

RE for vit. $B_{3}\left(l^{2}=92.6 \%, p=0.021\right)$

Vit. $B_{6}$

Sadowska and Krzymuska (2010)

Starbata et al. (2009)
RE for vit. $\mathrm{B}_{6}\left(I^{2}=98.7 \%, p=0.017\right)$

Vit. $B_{9}$

Sochacka-Tatara et al. (2008)

Starbała et al. (2009)

RE for vit. $B_{9}\left(I^{2}=94.6 \%, p=0.222\right)$

Vit. C

Sadowska and Krzymuska (2010)

Sochacka-Tatara et al. (2008)

Starbała et al. (2009)

RE for vit. C $\left(l^{2}=98 \%, p=0.001\right)$

Vit. D

Sochacka-Tatara et al. (2008)

Starbała et al. (2009)
Kostecka (2013/2014)

RE for vit. $D\left(l^{2}=99.3 \%, p=0.001\right)$

Vit. E

Vit. E
Sadowska and Krzymuska (2010)

Sadowska and Krzymuska (2010)
Sadowska et al. (2010)

Sochacka-Tatara et al. (2008)

Starbała et al. (2009)

RE for vit. E $\left(l^{2}=97.3 \%, p=0.895\right)$

Total random model effect for above factors

$\begin{array}{ll}N & \text { Mean } \\ & \\ 78 & 1662.0 \\ 105 & 1214.0 \\ 313 & 1194.0 \\ 31 & 1230.3 \\ 350 & 2670.0\end{array}$

$\begin{array}{ll}78 & 0.96 \\ 105 & 0.88 \\ 313 & 0.77 \\ 31 & 1.02\end{array}$

$\begin{array}{ll}78 & 1.56 \\ 313 & 1.30 \\ 31 & 1.78\end{array}$

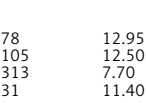

$\begin{array}{ll}313 & 7.70 \\ 31 & 11.40\end{array}$

$\begin{array}{ll}78 & 1.62 \\ 313 & 1.30 \\ 31 & 1.71\end{array}$

$\begin{array}{ll}313 & 0.19 \\ 31 & 0.20 \\ 350 & 0.06\end{array}$

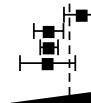

$\prod_{1}^{\infty}$

$\begin{array}{ll} & 0.22(-0.09-0.54) \\ & -0.36(-0.64 \text { to }-0.09) \\ & -0.37(-0.539-0.12)\end{array}$

$-0.37(-0.53$ to -0.21$)$
$-0.38(-0.89-0.12)$
$-4.02(3.6-4.27)$

$-0.38(-0.89-0.12)$
$4.02(3.76-4.27)$

$0.63(-1.05-2.30)$

$2.39(1.98-2.80)$
$1.27(0.97-1.56)$
0.76

$1.27(0.97-1.56)$
$0.76(0.60-0.92)$

$1.45(0.78-2.11)$

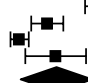

$29(2.81-3.78)$

$1.75(1.56-1.93)$
$2.08(1.46-2.70)$

$2.36(1.44-3.28)$

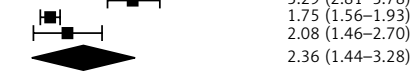

\begin{tabular}{ll}
$1.1-1$ & $2.38(1.97-2.79)$ \\
\hdashline-1 & $1.65(1.34-1.97)$ \\
& $1.02(0.0 .27-0.04)$ \\
\hline
\end{tabular}

$1.23(0.19-2.26)$
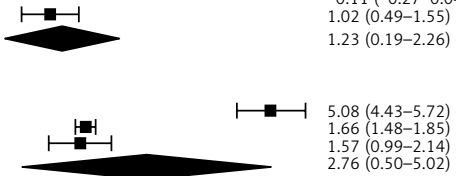

$\begin{array}{ll}78 & 75.6 \\ 105 & 75.8 \\ 313 & 90.3 \\ 31 & 85.8 \\ 350 & 90.2\end{array}$

$0.00(-0.50-0.50)$

$-0.54(-1.40-0.33)$

$.97(1.59-2.36)$

$0.73(0.57-0.89)$

$0.81(0.29-1.33)$

$0.96(0.46-1.47)$

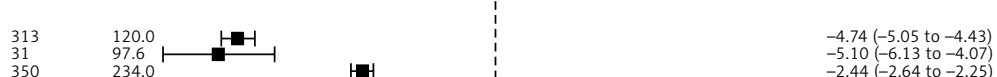

$-5.10(-6.13$ to -4.07$)$
$-2.44(-2.64$ to -2.25$)$

$-4.05(-5.68$ to -2.42$)$

$.21(0.87-1.55)$

$-0.33(-0.49$ to -0.18$)$

$0.64(0.13-1.15)$

$-0.09(-1.35$ to 1.18$)$

$0.57(-0.11-1.26)$

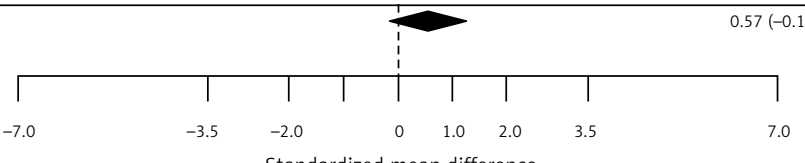

Figure 5. Effect size for standardized mean difference of selected factors (cont.)

in Crete [55], and in Portugal - where the norm was exceeded by over $80 \%$ in $7-9$-year-old children) [56] - collectively indicate that it is a serious global problem. In the case of children age 2.5-6.5 years in Belgium [46], 4-5 years in Greece [49] and 7 years in England [56], the norm was exceeded only in boys, by about $10 \%$. In the case of children aged $4-5$ years in Vietnam [50] and $<6$ years in the United States [57], the norm was exceeded in both sexes.

As Pawlak [58] has reported, adults in Poland also significantly exceed the recommendations of proper nutrition and pass on this habit to their children. According to FAO 2012, energy intake per person in Poland in 2006-2008 was 3410 kcal, which is equivalent to $173 \%$ of the minimum daily demand. The consumption of protein was also significantly exceeded (101 g/person/day), which is over two times more than the level indicated in the recommendations for proper nutrition.

An unbalanced diet causes insufficient intake of important nutrients, which in turn has a detrimental effect on the development of young organisms. Recently, the diet of children in highly developed countries has been characterized not only by high-energy foods and high content of protein and fat, but also by low content of vitamins and minerals. This is confirmed in the meta-analysis which demonstrated insufficiency of vitamin D. Vitamin D insufficiency leads to disturbed homeostasis of calcium in the body, which can lead to disturbed development of the skeletal system and can adversely affect teeth $[59,60]$. Studies also imply that vitamin D 
deficiency negatively affects insulin resistance and $\beta$-cell function $[61,62]$. Although vitamin intakes cannot be compared directly to the results of other studies (because of the age differences among the studied populations of children), it is interesting to note that similar, or even lower intakes of vitamin D were observed in British 7-year-olds [47], as well as in Spanish 6-9-yearolds [63] and Belgian 4-6.5-year-olds [46]. In combination with very low calcium intake (which was also confirmed by our meta-analysis), this effect can be exacerbated and lead to rickets or low final weight of the bone tissue, which in turn may lead to osteopenia or even osteoporosis, as well as an increase in the risk of fractures at an older age [64]. The results obtained for calcium are significantly lower than in other European countries (Belgium [46], Spain [51], Portugal [56] and England [65]). This is very surprising, taking into consideration the very strong promotion of drinking milk in Poland in recent years. Additionally, it is worth noting that the meta-analysis demonstrated that the level of phosphorous intake is significantly excessive. Maintaining the normal proportion of calcium and phosphorous is very important, but immensely difficult at the same time. Improper $\mathrm{Ca}$ : $\mathrm{P}$ ratio in the consumed food portions significantly deviating from the value accepted as normal can disturb the calcium-phosphorous balance, as well as regulatory processes and the metabolism of many substances in the body. This can result in, for example, a reduction of the peak bone mass in children and adolescents, and subsequently in an increase of bone deformations and fractures as well as osteoporosis [66].

The content of sodium is another index of a healthy diet. Similarly to vitamin intakes, mineral intakes are not directly comparable to other studies. It is important to note that in all the studies analysed by our authors [46, 48, 51, 55, 57, $63,65]$, sodium intake in children was between $100 \%$ and $250 \%$ higher than the recommended value. These results confirm the need to implement a programme limiting the intake of sodium, as it promotes water retention in the body and is one of the causes of arterial hypertension in adult life $[67,68]$. It is important to note that lifelong dietary habits are formed during childhood. Therefore, a high prevalence of salty foods in childhood may lead to a preference for salty tastes later in life. Additionally, excessive sodium intake may disturb the absorption of calcium, since sodium enhances excretion of calcium in urine [69].

Moreover, the intake was too high for magnesium and six of the nine analysed vitamins. Similar results were obtained in Belgium [46], Greece [55], and England [65].
There are several strengths of this study. An obvious one is that by combining studies, a metaanalysis increases the sample size and thus the power to study effects of interest. As far as is known, this is the first meta-analysis on nutrition of Polish preschool children in comparison to existing recommendations. Our research allows conclusions to be drawn about increased risk of dietdependent diseases in the later life of preschool children.

The meta-analysis detailed herein has certain limitations. Firstly, in the systematic review we identified 21 studies analysing the eating habits of children in Poland in the last decade, but only 10 of them could be used in the meta-analysis due to significant differences in the method of results presentation. Secondly, most of them are based on small samples. Thirdly, the greatest problem is the variety of measurement tools, which were not standard international tools, rendering comparison of results with other countries difficult. Often authors of these papers used their own tools for which they provided no information regarding the reliability and precision. This factor was the major cause of study heterogeneity.

In conclusion, the outcomes suggest that: (i) nutrient intake is not compliant with recommendations for this age group; (ii) the observed abnormalities may not only negatively affect the physical development of children, but also increase the risk of diet-related diseases in mature age - numerous studies demonstrate that cardiovascular risk factors and components of the metabolic syndrome with onset in childhood persist into adult life [70, 71], and obese children grow up into obese adults; (iii) the obtained results suggest that educational programmes (maybe even formal interventions) about proper diet need to be implemented for preschool children and their parents (e.g. the 15-week intervention programme "Junior for Seniors" concerning physical activity and nutrition conducted in 2015 [72]) - nutritional education at the earliest age can be a practical element of creating dietary behaviours, especially as the preschool period is a time when children have limited independent access to non-recommended foods, e.g. sweets and much depends on the behaviour of their parents or carers; (iv) no studies using standardized measurement tools have been carried out in Poland.

\section{Conflict of interest}

The authors declare no conflict of interest.

\section{References}

1. Recommendations for prevention of vitamin $D$ deficiency in Poland (2009). Med Wiek Rozw 2010; 14: 218-23. 
2. Moszczyński P. The impact of nutrition and food and a healthy lifestyle on the health of the population. Przegl Lek 2010; 67: 414-8.

3. Napiórkowska L, Franek E. The role of vitamin D in clinical practice. ChSiN 2009; 6: 203-10.

4. McGill AT, Stewart JM, Lithander FE, Strik CM, Poppitt SD. Relationships of low serum vitamin D3 with anthropometry and markers of the metabolic syndrome and diabetes in overweight and obesity. Nutr J 2008; 7: 4.

5. Kamycheva E, Joakimsen RM, Jorde R. Intakes of calcium and vitamin $\mathrm{D}$ predict body mass index in the population of Northern Norway. J Nutr 2003; 133: 102-6.

6. Gilbert-Diamond D, Baylin A, Mora-Plazas M, et al. Vitamin $D$ deficiency and anthropometric indicators of adiposity in school-age children: a prospective study. Am J Clin Nutr 2010; 92: 1446-51.

7. Rodríguez-Rodríguez E, Navia-Lombán B, López-Sobaler AM, Ortega RM. Associations between abdominal fat and body mass index on vitamin $D$ status in a group of Spanish schoolchildren. Eur J Clin Nutr 2010; 64: 461-7.

8. Alemzadeh R, Kichler J, Babar G, Calhoun M. Hypovitaminosis $D$ in obese children and adolescents: relationship with adiposity, insulin sensitivity, ethnicity, and season. Metabolism 2008; 57: 183-91.

9. Foss YJ. Vitamin D deficiency is the cause of common obesity. Med Hypotheses 2009; 72: 314-21.

10. Lagunova Z, Porojnicu AC, Lindberg F, Hexeberg S, Moan J. The dependency of vitamin D status on body mass index, gender, age and season. Anticancer Res 2009; 29: 3713-20.

11. Bryl W, Hoffmann K, Miczke A, Pupek-Musialik D. Obesity at an early age - epidemiology, health consequences, need for prevention. Przew Lek 2006; 9: 91-5.

12. Obuchowicz A. Epidemiology of overweight and obesity - an increasing health problem in children and adolescents. End Otył Zab Przem Materii 2005; 1: 9-12.

13. Sweeting $\mathrm{H}$. Measurement and definitions of obesity in childhood and adolescence: a field guide for the uninitiated. Nutrition J 2007; 9: 345-56.

14. Komiya H, Masubuchi Y, Mori Y, Tajima N. The validity of body mass index criteria in obese school-aged children. Tohoku J Exp Med 2008; 214: 27-37.

15. Ogden CL, Carroll MD, Kit BK, Flegal KM. Prevalence of obesity in the United States, 2009-2010. NCHS Data Brief 2012; 82: 1-8.

16. Wijnhoven TM, van Raaij JM, Spinelli A, et al. WHO European Childhood Obesity Surveillance Initiative 2008: weight, height and body mass index in 6-9-year-old children. Pediatr Obes 2013; 8: 79-97.

17. Guran T, Bereket A. International epidemic of childhood obesity and television viewing. Minerva Pediatr 2011; 63: 483-90.

18. Campos D, Hernández-Torres JJ, Agil A, et al. Analysis of food advertising to children on Spanish television: probing exposure to television marketing. Arch Med Sci 2016; 12: 799-807.

19. International Obesity Task Force: Childhood Report. IASO Newsletter 2004; 6: 10-1.

20. Mazur A, Rogozińska E, Mróz K, Ragan M, Mazur D, Małecka-Tendera E. The prevalence of overweight and obesity in preschool children in the Rzeszow region. Endoc Obes Metab Disor 2008; 4: 159-62.

21. Jarosz M, Buthak-Jachymczyk B (eds.). Standards of human nutrition. Fundamentals of prevention of obesity and noncommunicable diseases. IŻŻ, PZWL, Warszawa 2008.

22. Jarosz M (ed.). Normy żywienia dla populacji polskiej nowelizacja. IŻŻ, PZWL, Warszawa 2012.
23. Cicero AFG, Colletti A, Bajraktari G, et al. Lipid lowering nutraceuticals in clinical practice: position paper from an International Lipid Expert Panel. Arch Med Sci 2017; 13: 965-1005.

24. Rogalska-Niedźwiedź M, Charzewska J, Chabros E, et al. Nutrition of 40 year old children from rural and urban environments. Probl Hyg Epidem 2008; 89: 80-4.

25. Gawęcki J, Galiński G, Konieczka M, Kufel M. Quantitative and qualitative estimation of fat and carbohydrate intake by pre-school children from different communities and regions. J Med Sci 2005; 74: 393-5.

26. Sadowska J, Krzymuska A. Assessment of supplementing the school food rations of preschool children by parents. Nutr Sci Toxic Chem 2010; 2: 203-11.

27. Sochacka-Tatara E, Jacek R, Sowa A, Musiał A. Assessment of preschool children's diet. Probl Hyg Epidem 2008; 89: 389-94.

28. Sadowska J, Radziszewska M, Krzymuska A. Evaluation of nutrition manner and nutritional status of pre-school children. Acta Sci Pol Technol Aliment 2010; 9: 105-15.

29. Starbała A, Bawa S, Wojciechowska M, Weker H. Diet's energetic value and intake for macronutrients by obese and normosthenic children attending preschool. Nutr Sci Toxic Chem 2009; 3: 747-53.

30. Kolarzyk E, Janik A, Kwiatkowski J. Problems with assessment of relationship between contents of fatty tissue and caloric value of diet among pre-school children. Gen Med 2010; 16: 347-53.

31. Kostecka M. Proper nutrition preschool children as an essential element of prevention of lifestyle diseases. Nurs Pub Health 2013; 3: 257-63.

32. Merkiel S. Dietary intake in 6-year-old children from southern Poland: part 1 - energy and macronutrient intakes. BMC Pediatr 2014; 14: 197.

33. Kostecka M. Eating habits of preschool children and the risk of obesity, insulin resistance and metabolic syndrome in adults. Pak J Med Sci 2014; 30: 1299-303.

34. Charzewska J, Chwojnowska Z, Wajszczyk B. Energy and nutrient standards and their role in the development of pre-school children. In: Recommendations for Nutritionists on the Principles of Proper Nutrition for Children in Kindergartens. Charzewska J (ed.). IŻŻ, PZWL, Warszawa 2011; 31-52.

35. Jarosz M. Dietary reference intakes for the Polish population - amendment. IZZŻ, PZWL, Warszawa 2012.

36. Food and Nutrition Board of the Institute of Medicine: Dietary Reference Intakes for calcium and vitamin D. The National Academies Press, Washington 2011.

37. Hedges LV. Distribution theory for Glass's estimator of effect size and related estimators. J Educ Stat 1981; 6: 107-28.

38. Higgins JP, Thompson SG. Quantifying heterogeneity in a meta-analysis. Stat Med 2002; 21: 1539-58.

39. Higgins JP, Thompson SG, Deeks JJ, et al. Measuring inconsistency in meta-analyses. BMJ 2003; 327: 557-60.

40. R Core Team. R. A language and environment for statistical computing, http://www.R-project.org/ Accessed October 20, 2017.

41. Viechtbauer W. Conducting meta-analyses in $\mathrm{R}$ with the Metafor package. J Statist Soft 2010; 36: 1-48.

42. The conversion of effect size to percentages was adapted from Cohen J. Statistical Power analysis for the behavioral sciences. Erlbaum, Hillsdale 1988.

43. Wierzejska R. Importance of proper nutrition for preschool children. In: Recommendations for Nutritionists on the Principles of Proper Nutrition for Children in Kindergartens. Charzewska J (ed.). IZZŻ, PZWL, Warszawa 2011; 9-15. 
44. Januszek-Trzciąkowska A, Małecka-Tendera E, Klimek K, Matusik $P$. Obesity risk factors in a representative group of Polish prepubertal children. Arch Med Sci 2014; 10: 880-5.

45. Weatherholtz WM, Campbell TC, Webb R. Effect of dietary protein levels on the toxicity and metabolism of heptachlor. J Nutr 1969; 98: 90-6.

46. Huybrechts I, De Henauw S. Energy and nutrient intakes by pre-school children in Flanders-Belgium. Br J Nutr 2007; 98: 600-10.

47. Lin Y, Bolca S, Vandevijvere S, et al. Dietary sources of animal and plant protein intake among Flemish preschool children and the association with socio-economic and lifestyle-related factors. Nutr J 2011; 10: 97.

48. Glynn L, Emmett P, Rogers I, et al. Food and nutrient intakes of a population sample of 7-year-old children in the south-west of England in 1999-2000 - what difference does gender make? J Hum Nutr Diet 2005; 18: 7-19.

49. Manios Y. Desing and descriptive results of the "Growth, Exercise and Nutrition Epidemiological Study in preschool": the GENESIS Study. BMC Public Health 2006; 6: 32

50. Huynh DT, Dibley MJ, Sibbritt DW, Tran HT. Energy and macronutrient intakes in preschool children in urban areas of Ho Chi Minh City, Vietnam. BMC Pediatr 2008; 8: 44 .

51. Rodríguez-Artalejo F, Garcés C, Gorgojo L, et al. Dietary patterns among children aged 6-7 y in four Spanish cities with widely differing cardiovascular mortality. Eur J Clin Nutr 2002; 56: 141-8.

52. Sluijs I, Beulens JW, van der A DL, et al. Dietary intake of total, animal, and vegetable protein and risk of type 2 diabetes in the European prospective investigation into cancer and nutrition (EPIC)-NL Study. Diabetes Care 2010; 33: 43-8.

53. Cheng G, Buyken AE, Shi L, et al. Beyond overweight: nutrition as an important lifestyle factor influencing timing of puberty. Nutr Rev 2012; 70: 133-52.

54. Maillard G, Charles MA, Lafay L, et al. Macronutrient energy intake and adiposity in non-obese prepubertal children aged 5-11 y (the Fleurbaix Laventie Ville Santé Study). Int J Obes 2000; 24: 1608-17.

55. Smpokos EA, Linardakis M, Papadaki A, et al. Differences in energy and nutrient-intake among Greek children between 1992/93 and 2006/07. J Hum Nutr Diet 2014 27: $230-8$.

56. Moreira P, Padez C, Mourão I, Rosado V. Dietary calcium and body mass index in Portuguese children. Eur J Clin Nutr 2005; 59: 861-7.

57. Wright JD, Wang CY, Kennedy-Stephenson J, Ervin RB. Dietary intake of ten key nutrients for public health, United States: 1999-2000. Advance data from vital and health statistics; no.334. National Center for Health Statistics: Hyattsville, Maryland, 2003, www.gov.uk/government/uploads/system/uploads/attachment data/file/310995/NDNS Y1_to_4_UK_report.pdf Accessed August 04, 2017.

58. Pawlak K. Food Security in the European Union Countries. Economics and organization of the food economy. Zeszyty Naukowe SGGW w Warszawie 2012; 98: 39-52.

59. Hujoel PP. Vitamin D and dental caries in controlled clinical trials: systematic review and meta-analysis. Nutr Rev 2013; 71: 88-97.

60. Winzenberg T, Jones G. Vitamin D and bone health in childhood and adolescence. Calcif Tissue Int 2013; 92: 140-50.

61. Chiu KC, Chu A, Go VL, Saad MF. Hypovitaminosis D is associated with insulin resistance and beta cell dysfunction. Am J Clin Nutr 2004; 79: 820-5.
62. Sharifi F, Mousavinasab N, Mellati AA. Defining a cutoff point for vitamin $D$ deficiency based on insulin resistance in children. Diabetes Metab Syndr 2013; 7: 210-3.

63. Serra-Majem L, Ribas-Barba L, Pérez-Rodrigo C, Bartrina JA. Nutrient adequacy in Spanish children and adolescents. Br J Nutr 2006; 96: 49-57.

64. Ołtarzewski M, Szponar L, Rychlik E. Calcium consumption among children and teenagers in Poland. Hum Nut Metab 2003; 30: 278-83.

65. Wielgos B, Leszczyńska T, Kopeć A, Cieślik E, Piątkowska E, Pysz M. Assessment of intake of intake of minerals with diets by children aged 10-12 years from Malopolska Region. Rocz Panstw Zakl Hig 2012; 63: 329-37.

66. Great Britain Office for National Statistics Social Survey Division. National Diet and Nutrition Survey: young people aged 4 to 18 years. Volume 1: Report of the diet and nutrition survey. London, Stationery Office, 2000.

67. Booth JN $3^{\text {rd }}$, Colantonio LD, Howard G. et al. Healthy lifestyle factors and incident heart disease and mortality in candidates for primary prevention with statin therapy. Int J Cardiol 2016; 207: 196-202.

68. Mazidi M, Kengne AP, Mikhailidis DP, Cicero AF, Banach M. Effects of selected dietary constituents on high-sensitivity C-reactive protein levels in U.S. adults. Ann Med 2018; 50: 1-6.

69. Kleeman CR, Bohannan J, Bernstein D, et al. Effect of variations in sodium intake on calcium excretion in normal humans. Proc Soc Exp Biol Med 1964; 115: 29-32.

70. Sung RY, Tong PC, Yu CW, et al. High prevalence of insulin resistance and metabolic syndrome in overweight/ obese preadolescent Hong Kong Chinese children aged 9-12 years. Diabetes Care 2003; 26: 250-1.

71. Weiss R, Dziura J, Burgert TS, et al. Obesity and the metabolic syndrome in children and adolescents. N Engl J Med 2004; 350: 2362-74.

72. Bronikowski M, Bronikowska M, Pluta B, Maciaszek J, Tomczak M, Glapa A. Positive impact on physical activity and health behaviour changes of a 15-week family focused intervention program: "Juniors for Seniors". Biomed Res Int 2016; 2016: 5489348. 